\title{
Education and Training Program towards Work Achievement for Employees of Developer's Company
}

\author{
Dewi Yuliati \\ Faculty of Economics and Business, University of Pasundan \\ dyuliatiindah@yahoo.com
}

\begin{abstract}
The purpose of this research is to know the influence of education and training programs towards work's achievement for employees in developer's company Kota Bunga, Puncak, Cianjur Regency. Education and training programs consist of hardware and software dimension; as well as work achievement with the dimension of quantity and quality. Education and training variables were both assessed in terms of respondents' responses. The results reflect that most employees would assume that training is a very important. Work achievement is the contribution of individuals or groups either in quantity or in quality against the purpose of the company. Based on the respondents' responses, employees'work achievement is considered as excellent. Hypothesis test shows that there is a significant and positive influence on the program of education and training towards work achievement of employees.
\end{abstract}

Keywords: education, training, education and training programs, employee work achievement

\section{INTRODUCTION}

Human resources is a very important factor in the current tight competition, because it is an operational company mover tool with all the facilities available in the achievement of the goals. Increasing achievements to the employees is essential in achieving organization goals. This is one of ways for granting the education and training towards the employees.

The employees are expected to accept the challenge and be able to solve problems in their job. In the end, it can also satisfactorily support work achievements which necessarily support the existence of education and training in advance. In this case, the leader will need to give the opportunities to subordinate so that they can bring themselves good and reasonable down in the company.

The training was implemented in hard-wired expected in carrying out the duties of an employee and can enhance its activities in a more optimal way. With good activity expected level of the planned achievement, company goals will further increase.

Heidjrachman Ranupandojo and Suad Husnan (2008:70) noted that education is an activity to improve the general knowledge of a person including an increased mastery of the theory and skills and decided against the question that concerns activities in achieving the objectives. Exercise is an activity to improve the ability of the person's work in relation to economic activity. Exercise assist employees in understanding a practical and determinations, in order to improve the skills and attitudes required by the organization in an attempt to reach the goal.

Manullang (2008: 103) states that the utilities of the performance appraisal can be divided into several things. It is described as followed: repair work performance, adjustments of compensation, decisions of placement, needs of training and development, planning and career development, deviations process of staffing, lack of informational accuracy, error job design, job opportunities fair, challenge-hand external. Sutrisno, (2011: 151) states that the environmental factors that influence employee performance include physical condition, equipment, time, materials, education, supervision, organization design, training, and luck.

Those statements show that education and training is one of the efforts made by organizations in supporting the achievement of the desired objectives. As in this case, problem occurred in the company. It is decreasing (static) employee ability level which will automatically hamper the increasing of their career.

The training program was conducted for their needs and demands of the company to expand its efforts in facing the challenges and progress in the future in which education and training are basically the attempts to improve the activity of the employee in order to obtain optimal results. Therefore, the development, direction and motivation of human resources are the primary requirement. 
The problems usually encountered in implementing education and training among other things are related to less good drafting program education and training. Therefore, the result is not as expected, which in the end will negatively impact the increase on employee's work achievement. The most important resources compared to various resources used in producing the production of goods and service also include humans.

T. Hani Handoko (2008:103) purposes of education and training programs were held as follows:

1. To close the "gap" between the competence or ability of the employees with position's request.

2. To improve the efficiency and effectiveness of employees' work in reaching the targets set by the company.

Manulang (2009:84) states that the purpose of education and training are as follows: to raise the complacency, to reduce waste, to reduce absenteeism and to turn the employee over, to improve the work sytem and method, to raise the level of income, to reduce overtime costs, to reduce engine maintenance, to reduce complaints officers, to improve communication, to reduce accidents, to improve knowledge of mixeduse employees, to improve employee morale, to lead to better cooperation.

Moekijat (2008: 137) states as follows: (1). Education and training enables new employees to acquire greater knowledge. It means that adding some skills would be really necessary for the purpose of transfer and promotion. (2) If the employee has been given a reasonable level, then accidents, damage of engines and othe equipments could be minimized. (3) In order to hire better employees who participate in education and training. It can also grow faster. Education and training both reduce satisfaction, reduce absenteeism and worker turnover, since education and training can help individual prowess use completely, both for the old employees and new employees.

Whereas the benefits of education and training according to Alex S. Nitisemito, (2009: 92-93) are as follows: reducing supervision, increasing self-esteem, increasing cooperation among employee, facilitating the implementation of promotions and transfers, facilitating the implementation of authority delegation.

From the definitions mentioned above, the programs have two benefits. First is a benefit for the company which acquires trained and equipped employee to handle certain occupation. And the second is a benefir for employee which will increase their knowledge and skills in the field of employment and is expected to improve the quality of the employee itself.

In line with the theory of human capital, higher average education levels are positively related to higher labour productivity. The incidence and duration based measures of training are both positively related to financial performance and labour productivity, although a more mixed pattern is evident for quality (Jones, et.al., 2008). Highly educated workers tend to display greater creativity and to demonstrate more citizenship behaviours than do less educated workers. Moreover, highly educated workers appear to engage in fewer counter productive work behaviours like workplace aggression, workplace substance use, and absenteeism (Ng and Fieldman, 2013).

Training is positively and significantly associated to job satisfaction. Job satisfaction is also positively and significantly associated to the workplace performance on most measures of performance. The relationship between performance and training is more complicated, with the relationships depending on the features of training and measure of performance considered (Jones, et. al., 2008).

Training and development are continuous process in improving the calibre of employees. It is an attempt to improve their current and future performance but the organization should keep a track on their performance after imparting them training. It means training needs assessment which is a systematic process of altering the behaviour of employees in a direction to achieve the organization's goals (Anim, et.al., 2013).

There is importance of positive relationship related to the training and worker performance. Training is not beneficial for employee since it's ultimately beneficial for development of the organization. If the performance of employee is good, it is going to affect the entire organization in optimistic way (Shaheen, 2013).

Education and training programs will generate employees to higher ability, more creative, more productive and exhibit behaviour that ultimately increases employee performance. However, it should also be noted that the program features (such as time and type) are offered and will be used to measure employees' work achievement.

The influence of education and training programs on employee work achievement can be described as followed:

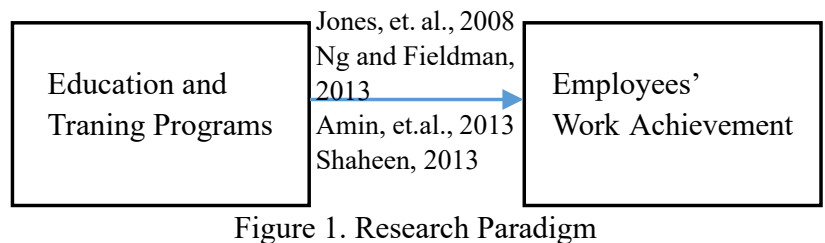

Hypothesis: Education and Training Program influence on Employees' Work Achievement.

\section{METHOD}

The method used in this research is descriptive and quantitative method. Descriptive method is used to describe the education and training programs and employee work achievement in Kota Bunga, Puncak. Quantitative method is used to determine the relationship and the influence of education and training programs on the work achievement of employees in 
Kota Bunga Puncak. The data obtained are primary and secondary. Primary data is obtained from interviews with respondents, all employees, and the field survey through questionnaires. Secondary data is obtained from the company's data of Kota Bunga Puncak and literature.

Table 1. Operationalization Variable

\begin{tabular}{|c|c|c|}
\hline Variable & Dimension & Indicator \\
\hline $\begin{array}{l}\text { Education and Training } \\
\text { Program } \\
\text { Part of education process } \\
\text { which aims to improve the }\end{array}$ & Software & $\begin{array}{l}\text { - Instructor } \\
\text { - Training } \\
\text { Methods } \\
\text { - Training } \\
\text { Material }\end{array}$ \\
\hline $\begin{array}{l}\text { ability or specific skills of a } \\
\text { person or group of people. }\end{array}$ & Hardware & $\begin{array}{l}\text { - Place } \\
\text { - Tools }\end{array}$ \\
\hline $\begin{array}{l}\text { Employees, work } \\
\text { achievement } \\
\text { (Y) } \\
\text { Employees, work } \\
\text { achievement is the } \\
\text { result of the quality and }\end{array}$ & Quantity & $\begin{array}{l}\text { - Attendance } \\
\text { - Achievement of } \\
\text { the job targets } \\
\text { - Speed of } \\
\text { completing the } \\
\text { job }\end{array}$ \\
\hline $\begin{array}{l}\text { quantity of the work } \\
\text { accomplished by an } \\
\text { employee in performing } \\
\text { their duties according to } \\
\text { the responsibilities given } \\
\text { to them. }\end{array}$ & Quality & $\begin{array}{l}\text { - Meticulous } \\
\text { - Involvement in } \\
\text { the filling of self } \\
\text { - Full } \\
\text { concentration }\end{array}$ \\
\hline
\end{tabular}

\section{RESULTS}

Characteristics of respondents who are employees of the population in Kota Bunga, Puncak in Cianjur. The characteristic of the respondents is based on age and identified as Table 2.

Table 2. Characteristic of Respondents by Age

\begin{tabular}{cccc}
\hline Number & Age & Frequency & Percentage(\%) \\
\hline 1 & $20-27$ & 8 & 40 \\
2 & $28-35$ & 2 & 10 \\
3 & $>36$ & 10 & 50 \\
\hline \multicolumn{5}{c}{ Total } & 20 & 100
\end{tabular}

Source: Data Processing Questionnaire January 2016

Table 2 is based on the respondents' average age and is in a productive position. They are considered as people who can still work and perform better. The majority is over 36 years old, therefore it has an adequate maturity. Characteristic of respondents by gender is identified Table 3.

Table 3. Characteristics of Respondents by Gender

\begin{tabular}{cccc}
\hline Number & Gender & Frequency & Percentage(\%) \\
\hline 1 & Female & 8 & 30 \\
2 & Male & 12 & 70 \\
\hline & Total & 20 & 100 \\
\hline
\end{tabular}

Source: Data Processing Questionnaire January 2016
Based on Table 3, female employees are less than male. Moreover, characteristic of respondents which is based on education is identified in Table 4 .

Table 4. Characteristics of Respondents by Education

\begin{tabular}{cccc}
\hline Number & Education & Frequency & Percentage(\%) \\
\hline 1 & High School & 10 & 70 \\
2 & Bachelor(S1) & 6 & 20 \\
3 & Master (S2) & 4 & 10 \\
\hline \multicolumn{5}{c}{ Total } & 20 & 100 \\
\hline
\end{tabular}

Source: Data Processing Questionnaire January 2016

Based on Table 4, most of the employees are graduated from high school. Furthermore, characteristics of employees based on position is shown in Table 5.

Table 5. Characteristics of Respondents by Job's positon

\begin{tabular}{cccc}
\hline Number & Position & Frequency & Percentage(\%) \\
\hline 1 & Top & 4 & 10 \\
2 & Middle & 6 & 20 \\
3 & Lower & 10 & 70 \\
\hline & Total & 20 & 100
\end{tabular}

Source: Data Processing Questionnaire January 2016

Based on Table 4 and 5, it appears that the higher positions is occupied by employees with higher education. This shows that developers in Kota Bunga Puncak in Cianjur has already put employees in accordance with their education. Employees with higher education earn higher positions compared to those who are in lesser education.

Training is a process which will change behavior in the form of upgrades including cognitive, affective, and psychomotor. Training needs to be given to employees to determine the response of respondents to the training, following the value of the respondents about the dimensions that must be observed in training.

Respondents to the variables training education program is considered good, in terms of respondents which reached to $75.12 \%$ with tabulation as Table 6 .

Table 6. Score Education and Training Variables

\begin{tabular}{cc}
\hline Dimension & Percentage (\%) \\
\hline Software & $69.29 \%$ \\
Hardware & $80.95 \%$ \\
\hline Average & $75.12 \%$ \\
\hline
\end{tabular}

The developer's company of Kota Bunga Puncak in Cianjur still needs to improve the training of educational software aspects, which include instructors, methods, and training materials. It is because the employee response is below the average. The developer can maximize the benefits of training by paying attention to assessment needs and pertaining states of trainees (e.g., trainee motivation), training design and delivery (e.g., advantages of using error training), training evaluation (e.g., documenting training success differently depending 
on the stakeholder in question) and transfer of training (i.e., the importance of interpersonal factors), Anam, et. al. (2013).

Work achievement shown by employees has greatly contributed to the achievement goals or targets that have been set by the company. This means any company that wants to develop must always strive to acquire employees who excel. In terms of attention to employees, especially employees who have accomplishments in the job. Because the work achievement is the success of a worker in running an arduous task and will give them contentment.

The results are in line to research $\mathrm{Ng}$ and Fieldman (2009) have done. They stated that the educational has influence to the employee work achievement. Similarly, Jones et.al. (2008) stated that the training positively and significantly affect the performance. Anim, et.al. (2013) stated that the training and development program will increase the competence of employees thus increasing work achievement. Shaheen (2013) stated that a training program is related to employee's performance.

The Developer's company of Kota Bunga Puncak in Cianjur must pay attention for training. It is because turnover is higher in workplaces where a higher proportion of workers is over-skilled. This probably shows that the workers are seeking suitable jobs to their capability. Similarly, the higher turnover rates in firms with higher average education levels might be due to the availabilityof opportunities for educated workers (Jones, 2008).

\section{CONCLUSION}

Conclusions proposed in this reseach are as followed:

1. Education and training programs in Kota Bunga Puncak in Cianjur should be further enhanced, particularly related to the software including instructor, methods, and training materials. It is also related to how to manage and schedule routine and to align with each employee career paths.

2. The work achievement of employees in Kota Bunga's company developer will be further increased by the education and training programs, especially if the program is used as a mandatory program that applies to all employees in accordance with the carrier path where it is expected to. It will also create better performance of each employee to develop company's improvement.

3. Education and training programs have given influence on work achievement of employees at the company's developer in Kota Bunga Puncak in Cianjur. Education and better training, includes the software and hardware can improve work achievement of employees.

\section{REFERENCES}

Anam, Amin; Rashid Saeed., Mr Rab Nawaz Lodhi; Mizna; Simra: Anam Iqbal and Rida-e-Tehreem. 2013. The Impact of Employees Training On the Job Performance in Education Sector of Pakistan. Middle-East Journal of Scientific Research 17 (9): 1273-1278,

Handoko, Hani. 2008. Manajemen Sumber Daya Manusia. Edisi Kedua, Liberty, Yogyakarta.

Heidjrachman dan Suad Husnan. 2007. Manajemen Personalia. Edisi 4. Yogyakarta: BPFE

Jones, Melanie K; Richard J. Jones; Paul L. Latreille; Peter J. Sloane. 2008. Training, Job Satisfaction and Workplace Performance in Britain : Evidence from WERS, 2004. ISA Discussion Paper Series DP No. 3677. http://ftp.iza.org/dp3677.pdf.

Manullang M, 2009, Dasar-dasar Manajemen, Cetakan Ke-empat belas, Ghalia Indonesia, Jakarta.

Moekijat. 2009. Manajemen Kepegawaian, Cetakan Ke-enam, Alumni, Bandung.

Ng, Thomas, W. H. and Daniel C. Fieldman. 2009. How Broadly Does Education Contributie to Job Performance? Personnel Psychology. 62. 89-134. http:// homepage.se.edu/cvonbergen/files/2013/01.

Nitisemito, Alex, S. 2009. Manajemen Personalia, Ghalia Indonesia, Jakarta.

Shaheen, Azara; Syed Mubasher Hussain Naqvi; Muhammad Atif Khan. 2013. Employees Training and Organizational Performance: Mediation by Employees Performance. Interdiciplinary Journal of Contemporary Research in Business. August 2013, Vol. 4 No. 5.

Sutrisno, A. and Lee, T.J., 2011. Service reliability assessment using failure mode and effect analysis (FMEA): survey and opportunity roadmap. International Journal of Engineering, Science and Technology, 3(7), pp.25-38. 